\title{
Effect of Different Fertilization Rates on Cyanogen and Foliage and Tuber Yields of Cassava
}

\author{
Yin Yin Kyawt ${ }^{1}$, Achara Lukkananukool ${ }^{2}$, Win Mi Htwe ${ }^{3} \&$ Min Aung ${ }^{1}$ \\ ${ }^{1}$ Department of Animal Nutrition, University of Veterinary Science, Nay Pyi Taw, 15013, Myanmar \\ 2 Department of Animal Production Technology and Fisheries, Faculty of Agricultural Technology, King \\ Mongkut's Institute of Technology Ladkrabang, Bangkok, 10520, Thailand \\ ${ }^{3}$ Livestock Breeding and Veterinary Department, Nay Pyi Taw, 15013, Myanmar \\ Correspondence: Yin Yin Kyawt, Department of Animal Nutrition, University of Veterinary Science, Nay Pyi Taw, \\ 15013, Myanmar. E-mail: dr.yinyinkyawt81@gmail.com
}

Received: May 26, 2020 Accepted: June 21, 2020 Online Published: June 23, 2020

\begin{abstract}
This experiment was conducted to determine the effect of different fertilization rates on the cyanogen and yields of cassava foliage and tuber. Nine fertilization rates, three nitrogen and potassium levels $(\mathrm{N}: 0,50,100 \mathrm{~kg} / \mathrm{ha}$ and $\mathrm{K}: 0,100,250 \mathrm{~kg} / \mathrm{ha}$, respectively) with constant phosphorus level (P: $50 \mathrm{~kg} / \mathrm{ha})\left(\mathrm{F}-0: \mathrm{N}_{0}-\mathrm{P}_{50}-\mathrm{K}_{0}, \mathrm{~F}-1: \mathrm{N}_{0}-\mathrm{P}_{50}-\mathrm{K}_{100}\right.$, F-2: $\mathrm{N}_{0}-\mathrm{P}_{50}-\mathrm{K}_{250}, \mathrm{~F}-3: \mathrm{N}_{50}-\mathrm{P}_{50}-\mathrm{K}_{0}, \mathrm{~F}-4: \mathrm{N}_{50}-\mathrm{P}_{50}-\mathrm{K}_{100}, \mathrm{~F}-5: \mathrm{N}_{50}-\mathrm{P}_{50}-\mathrm{K}_{250}, \mathrm{~F}-6: \mathrm{N}_{100}-\mathrm{P}_{50}-\mathrm{K}_{0}, \mathrm{~F}-7: \mathrm{N}_{100}-\mathrm{P}_{50}-\mathrm{K}_{100}, \mathrm{~F}-8: \mathrm{N}_{100}-$ $\mathrm{P}_{50}-\mathrm{K}_{250}$ ), were applied in the randomized completely block design. After one year experiment, cassava foliage and tuber were harvested, and determined the yields and cyanogen $(\mathrm{HCNp})$ content. The lowest $(\mathrm{P}<0.05) \mathrm{HCNp}$ contents and the highest $(\mathrm{P}<0.05)$ foliage, tuber and protein yields were observed in cassava applied with F-4 $\left(\mathrm{N}_{50}-\mathrm{P}_{50}-\mathrm{K}_{100}\right)$ and $\mathrm{F}-5\left(\mathrm{~N}_{50}-\mathrm{P}_{50}-\mathrm{K}_{250}\right)$ in compare with other fertilization rates. Regarding growth characteristics, the plant height $(\mathrm{P}<0.05)$ was also highest in cassava fertilized by F-4 $\left(\mathrm{N}_{50}-\mathrm{P}_{50}-\mathrm{K}_{100}\right)$ and F-5 $\left(\mathrm{N}_{50}-\mathrm{P}_{50}-\mathrm{K}_{250}\right)$, whereas the leaf numbers per plant and branches number per plant were highest in cassava applied with F-5 $\left(\mathrm{N}_{50^{-}}\right.$ $\left.\mathrm{P}_{50}-\mathrm{K}_{250}\right)$ and F-7 $\left(\mathrm{N}_{100}-\mathrm{P}_{50}-\mathrm{K}_{100}\right)$, respectively. It could be recommended that the nitrogen $(\mathrm{N}: 50 \mathrm{~kg} / \mathrm{ha})$ and potassium (K: $100-250 \mathrm{~kg} / \mathrm{ha}$ ) should be used to reduce cyanogen contents for safe utilization and increased cassava foliage and tuber yields.
\end{abstract}

Keywords: Cassava, nitrogen, potassium, $\mathrm{HCNp}$, yield

\section{Introduction}

Cassava (Manihot esculenta, Crantz) is one of the important crops in tropical regions of the world and cassava tubers are very rich in carbohydrates, a major source of energy. It has been reported that cassava can produce the highest carbohydrate (calorie/ha/day) compared to other staple crops such as rice, wheat, maize and sorghum (Okigbo, 2001). Cassava tubers are used as human food, animal feed and industrial raw material (Nambisan, 2010). Cassava leaves, a by-product after cassava tuber harvest are generally rich in crude protein $(\mathrm{CP})$, minerals, vitamin B1, B2, C and carotenes (Eggum, 1970). However, the major constraint with the use of cassava foliage as animal feed is the risk of hydrocyanic acid potential (HCNp) toxicity (Gomez et al., 1980). Surprisingly, despite its availability and high $\mathrm{CP}$ content, there was little interest until recently to utilize fresh cassava foliage in ruminant feeding. This reluctance is probably related to the possibilities of cyanide toxicity.

To achieve the yield potential of cassava, good soil fertility and adequate fertilization are essential (Gomez et al., 1980). The major nutrients required by cassava for optimum top growth and tuber yields are nitrogen $(\mathrm{N})$ and potassium (K). Cassava plant is well adapted to low levels of available phosphorus (P) but requires fairly high levels of $\mathrm{N}$ and $\mathrm{K}$, especially when grown for many years on the same plot or continuously cultivated plots (Ayoola and Makinde, 2007). Adequate $\mathrm{K}$ levels in soil stimulate response to $\mathrm{N}$ fertilizers but the excess amount of both nutrients leads to luxuriant growth at the expense of tuber formation (Onwueme and Charles, 1994). Howler (1985) reported that the application of $\mathrm{K}$ increases starch content and decreases HCNp level. On the other hand, the application of increases $\mathrm{N}$ level progressively increases the HCNp content (Sher et al., 2012). Hence, the need to upgrade the existing fertilizer recommendations in sustainable cassava production is imperative. However, suitable fertilizer use with minimum polluting effects on the environment should be the major rule. For most crops, the best fertilizer types, rates and time of application were not known and this constituted a major constraint to fertilizer use in the country (Sarfo et al., 1998). Several studies have documented the proximate composition, amino acid 
profile (Rogers and Milner, 1963), and mineral content of cassava foliage (Ravindran et al., 1982), but in none was the HCNp content elucidated in relation to the different rates of fertilizer (N-K). Few published reports focus on agronomic management or cultivation practices for optimizing cassava foliage together with tuber production. Therefore, the objectives of the present study were to determine the effect of different fertilization rates on the cyanogen and yields of cassava foliage and tuber.

\section{Materials and Methods}

\subsection{Experimental Location and Climate Condition}

This experiment was carried out at the experimental field of the University of the Ryukyus, Okinawa, Japan. The climate data during experimental period (Figure 1) were obtained from Japan Meteorological Agency.

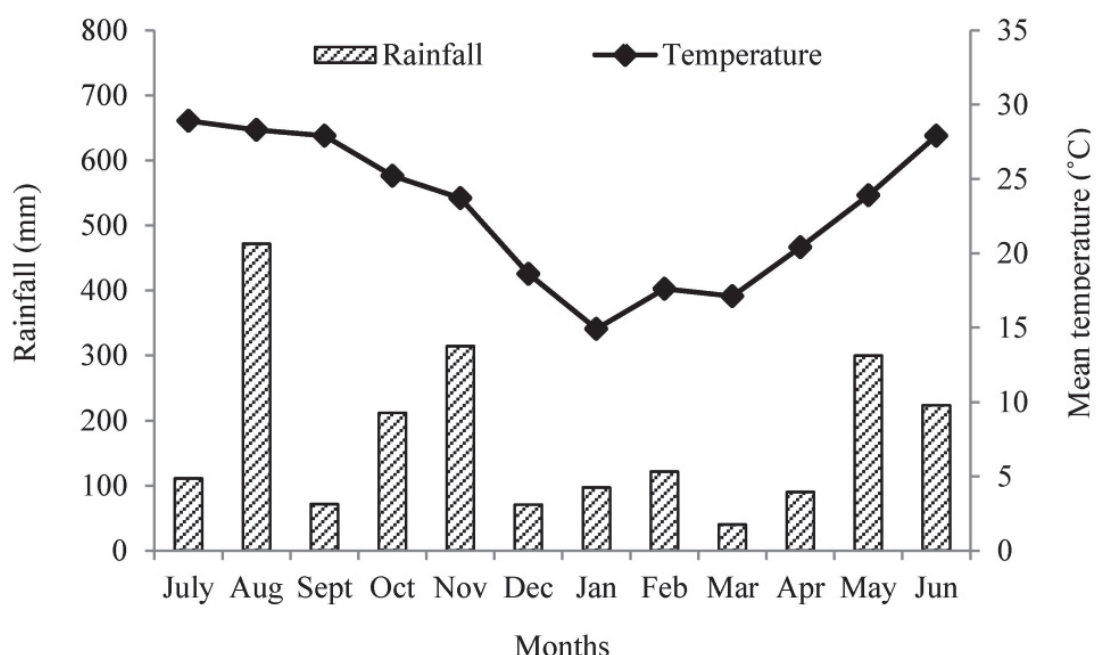

Figure 1. Climate data (rainfall and mean temperature) during experimental period

\subsection{Land Preparation}

Pre-treatment soil samples for soil analysis were taken before land preparation and fertilizer treatment. The soil fertility status before the commencement of the experiment was shown in Table 1. The type of soil in the experimental area is gray soil (locally named Jagaru). Before plantation, the area $\left(122 \mathrm{~m}^{2}\right)$ for cassava plantation was ploughed with a machine about $20 \mathrm{~cm}$ depth.

Table 1. Soil nutrient composition for the $0-20 \mathrm{~cm}$ layer of the soil at the experimental site

\begin{tabular}{lr}
\hline Parameters & Values \\
\hline $\mathrm{pH}\left(\mathrm{H}_{2} \mathrm{O}\right)$ & 8.15 \\
Total N (\%) & 0.14 \\
Available P (ppm) & 56.52 \\
Exchangeable K (meq $\left.100 \mathrm{~g}^{-1}\right)$ & 0.26 \\
$\mathrm{Na}\left(\right.$ meq $\left.100 \mathrm{~g}^{-1}\right)$ & 0.24 \\
$\mathrm{Ca}\left(\right.$ meq $\left.100 \mathrm{~g}^{-1}\right)$ & 35.40 \\
$\mathrm{Mg}\left(\mathrm{meq} 100 \mathrm{~g}^{-1}\right)$ & 1.97 \\
\hline
\end{tabular}

$\mathrm{P}=$ phosphorus, $\mathrm{K}=$ potassium, $\mathrm{Na}=$ sodium, $\mathrm{Ca}=$ calcium, $\mathrm{Mg}=$ magnesium

\subsection{Experimental Treatments and Design}

The combination of three nitrogen $(\mathrm{N})$ level $(0,50,100 \mathrm{~kg} / \mathrm{ha})$ and three potassium $(\mathrm{K})$ level $(0,100,250 \mathrm{~kg} / \mathrm{ha})$ with constant phosphorus level (50 kg/ha), total nine fertilization rates (F-0: $\mathrm{N}_{0}-\mathrm{P}_{50}-\mathrm{K}_{0}, \mathrm{~F}-1: \mathrm{N}_{0}-\mathrm{P}_{50}-\mathrm{K}_{100}, \mathrm{~F}-2: \mathrm{N}_{0}-$ $\left.\mathrm{P}_{50}-\mathrm{K}_{250}, \mathrm{~F}-3: \mathrm{N}_{50}-\mathrm{P}_{50}-\mathrm{K}_{0}, \mathrm{~F}-4: \mathrm{N}_{50}-\mathrm{P}_{50}-\mathrm{K}_{100}, \mathrm{~F}-5: \mathrm{N}_{50}-\mathrm{P}_{50}-\mathrm{K}_{250}, \mathrm{~F}-6: \mathrm{N}_{100}-\mathrm{P}_{50}-\mathrm{K}_{0}, \mathrm{~F}-7: \mathrm{N}_{100}-\mathrm{P}_{50}-\mathrm{K}_{100}, \mathrm{~F}-8: \mathrm{N}_{100}-\mathrm{P}_{50}-\mathrm{K}_{250}\right)$ 
were used in this experiment. Total of 27 plots for 9 treatments ( 3 replicates for each treatment) were arranged according to the randomized completely block design (RCBD). Each plot has $1.5 \mathrm{~m} \times 3 \mathrm{~m}$ in size. Irrigation was applied when the rainfall was low, especially summer time. As the weed management, all weed were cleaned by hand monthly.

\subsection{Cassava Plantation, Fertilizer Application and Sample Collection}

The variety of cassava used in this experiment was a local variety called Red cassava, due to the red colour of the petiole. Old cassava stems, which were obtained after cutting into about $20 \mathrm{~cm}$ were planted in continuous rows with $0.5 \mathrm{~m}$ between rows, $1 \mathrm{~m}$ between stalks in the same row. All experimental fertilizers were applied at the time of the first leaf that appeared from cassava stand at one month after planting. Foliage and tubers were harvested at the age of 12 months and their weights are taken per stand to determine the yielding of cassava foliage and tuber. The fresh samples were dried at $60^{\circ} \mathrm{C}$ in a forced air oven for $48 \mathrm{~h}$. Dried samples were ground and passed through a sieve of approximately $0.5 \mathrm{~mm}$ for the further analysis.

\subsection{Chemical Analysis}

The soil quality such as total nitrogen $(\mathrm{N})$, available phosphorus $(\mathrm{P})$ and exchangeable potassium $(\mathrm{K})$, sodium $(\mathrm{Na})$, calcium $(\mathrm{Ca})$, and magnesium $(\mathrm{Mg})$ of soil were determined by micro-Kjeldahl method (AOAC, 1990), the methods described by Truog (1930) and Peech et al., (1962), respectively. The dry matter (DM) and crude protein (CP) contents of cassava foliage and tubers were analyzed using the procedures described by AOAC (1990). The measurement of HCNp content was analyzed by using the acid hydrolysis method (Bradbury et al., 1991) and continued with a spectrophotometer (O’Brien et al., 2007).

\subsection{Statistical Analysis}

The data were subjected to the analysis of variance (ANOVA) and the significance of differences between means was compared by Duncan's Multiple Range Test (DMRT) using SPSS (version 16.0) software. The significant differences were considered at $\mathrm{P}<0.05$.

\section{Results and Discussion}

The application of fertilizer significantly affected the HCNp content of foliage and tuber in this experiment (Table 2 ). The minimum HCNp content $(\mathrm{P}<0.05)$ in cassava foliage was obtained by the application of $\mathrm{F}-4$ followed by F-5. However, the difference between F-4 and F-5 was not significant $(\mathrm{P}>0.05)$ in this experiment. A similar result was observed in the HCNp content of tuber by the application of F-5 followed by F-4 at the final harvesting time of tuber. Moreover, the application of N-K treatments in tuber had significantly lower $(\mathrm{P}<0.05) \mathrm{HCNp}$ content than those of the control treatment. Therefore, it is evident that the lowest level of HCNp content was observed at F-4 and F-5 fertilization rates in both foliage and tuber. The HCNp reduction as influenced by N-K fertilization compared with the control treatment for foliage and tuber was also presented in Table 2.

Table 2. Effect of fertilizer application on hydrocyanic acid potential (HCNp) content of cassava foliage and tuber

\begin{tabular}{lccccc}
\hline \multirow{2}{*}{$\begin{array}{l}\text { Fertilization rate } \\
\text { N-P-K }(\mathrm{kg} / \mathrm{ha})\end{array}$} & $\begin{array}{c}\mathrm{HCNp} \\
(\mathrm{mg} / \mathrm{kg} \mathrm{DM})\end{array}$ & $\begin{array}{c}\text { FCNp } \\
\text { reduction }(\%)\end{array}$ & & $\begin{array}{c}\text { HCNp } \\
(\mathrm{mg} / \mathrm{kg} \mathrm{DM})\end{array}$ & $\begin{array}{c}\text { Tuber } \\
\text { reduction }(\%)\end{array}$ \\
\hline F-0 $\left(\mathrm{N}_{0}-\mathrm{P}_{50}-\mathrm{K}_{0}\right)$ & $129.49^{\mathrm{a}}$ & $0.00^{\mathrm{b}}$ & & $95.66^{\mathrm{a}}$ & $0.00^{\mathrm{c}}$ \\
F-1 $\left(\mathrm{N}_{0}-\mathrm{P}_{50}-\mathrm{K}_{100}\right)$ & $80.01^{\mathrm{ab}}$ & $38.21^{\mathrm{a}}$ & & $65.55^{\mathrm{b}}$ & $31.47^{\mathrm{b}}$ \\
F-2 $\left(\mathrm{N}_{0}-\mathrm{P}_{50}-\mathrm{K}_{250}\right)$ & $87.53^{\mathrm{ab}}$ & $32.41^{\mathrm{ab}}$ & & $66.62^{\mathrm{b}}$ & $30.35^{\mathrm{b}}$ \\
F-3 $\left(\mathrm{N}_{50}-\mathrm{P}_{50}-\mathrm{K}_{0}\right)$ & $76.82^{\mathrm{ab}}$ & $40.67^{\mathrm{a}}$ & & $55.37^{\mathrm{b}}$ & $42.11^{\mathrm{b}}$ \\
F-4 $\left(\mathrm{N}_{50}-\mathrm{P}_{50}-\mathrm{K}_{100}\right)$ & $51.89^{\mathrm{b}}$ & $59.93^{\mathrm{a}}$ & & $34.02^{\mathrm{c}}$ & $64.44^{\mathrm{a}}$ \\
F-5 $\left(\mathrm{N}_{50}-\mathrm{P}_{50}-\mathrm{K}_{250}\right)$ & $54.77^{\mathrm{b}}$ & $57.70^{\mathrm{a}}$ & & $31.97^{\mathrm{c}}$ & $66.58^{\mathrm{a}}$ \\
F-6 $\left(\mathrm{N}_{100}-\mathrm{P}_{50}-\mathrm{K}_{0}\right)$ & $86.43^{\mathrm{ab}}$ & $33.25^{\mathrm{ab}}$ & & $59.11^{\mathrm{b}}$ & $38.21^{\mathrm{b}}$ \\
F-7 $\left(\mathrm{N}_{100}-\mathrm{P}_{50}-\mathrm{K}_{100}\right)$ & $67.01^{\mathrm{ab}}$ & $48.25^{\mathrm{a}}$ & & $54.94^{\mathrm{b}}$ & $42.57^{\mathrm{b}}$ \\
F-8 $\left(\mathrm{N}_{100}-\mathrm{P}_{50}-\mathrm{K}_{250}\right)$ & $66.85^{\mathrm{ab}}$ & $48.37^{\mathrm{a}}$ & & $50.95^{\mathrm{b}}$ & $46.73^{\mathrm{b}}$ \\
\hline SEM & 4.41 & 3.39 & 0.0001 & 3.62 & 3.76 \\
P value & 0.0001 & & & 0.0001 & 0.0001 \\
\hline
\end{tabular}

${ }^{\mathrm{a}-\mathrm{c}}$ Values with different superscript on the same column are significantly different $(\mathrm{P}<0.05)$.

In literature, the ranges of the HCNp content of different varieties of cassava contain 1-1550 mg/kg (Cardoso et al., 2005). The average values of HCNp content in the present results are included in the range of low HCNp levels compared to the recent report of Hue et al., (2012). The amount of HCNp content in cassava varies even different parts of the same plant according to variety, its age, geographical locations and other factors like soil, fertilization 
and climate also contribute to the quantities of HCNp in the plants (Bradbury et al., 1999). In this experiment, a higher rate of $\mathrm{N}$ application tended to increase in $\mathrm{HCNp}$ content and it was observed in F-6, F-7, F-8 compared with F-4 and F-5 treatments. Therefore, it could be reasoned that the suitable quantity of N fertilizer application would encourage plant growth to the climax, but the excess dose would enhance to increase the HCNp content. Sher et al., (2012) also revealed that an increase in N application resulted in an enhanced HCNp level. Furthermore, Peter and Birger (2002) stated that the applied N stimulates the enzymatic conversion of tyrosine to phydroxymandelonitrile which ultimately leads to an increase in the biosynthesis of cyanogenic glucoside. Worthington (2001) also stated that plants require $\mathrm{N}$ for normal growth and protein synthesis however, if $\mathrm{N}$ is applied over what the plant requires for protein formation, the excess is accumulated as nitrate and stored predominantly in the green leaf part of the plant. The highest value of HCNp reduction was observed in F-4 and F-5 in this experiment. Therefore, the appropriate combination rate of $\mathrm{N}$ and $\mathrm{K}$ are required for cassava cultivation concerning for the $\mathrm{HCNp}$ reduction. The same trend of $\mathrm{HCNp}$ reduction as influenced by fertilization was observed in the tuber. From this result, the combined N-K treatment showed a higher HCNp reduction than the individual treatment of either $\mathrm{N}$ or $\mathrm{K}$. Therefore, the HCNp content in tuber clearly showed that both $\mathrm{N}-\mathrm{K}$ applications promote the $\mathrm{HCNp}$ reduction. Moreover, the highest $\mathrm{HCNp}$ reduction with the minimum $\mathrm{HCNp}$ content in tuber was observed in the higher dose of K namely F-5 followed by F-4 in this experiment. Therefore, the results obtained in this experiment are consistent with the report of Howeler (2002). Putthacharoen et al. (1998) stated that cassava removed less $\mathrm{N}$ and $\mathrm{P}$ but similar amounts of $\mathrm{K}$ in the harvested plant parts as compared to maize, sorghum, peanut, mung bean, pineapple and sugarcane. Long-term fertility trials indicate that without adequate $\mathrm{K}$ fertilizer, in this case referring to tuber production, cassava yields eventually decline due to $\mathrm{K}$ depletion, except in those soils containing large amounts of K-bearing minerals (Howeler, 1985).

The CP yields in foliage and tuberous roots of cassava were summarized in Table 3 and 4, respectively. The high $(\mathrm{P}<0.05) \mathrm{CP}$ yield $(356.24-404.79 \mathrm{~kg} / \mathrm{ha})$ in the foliage were obtained in F-4, F-5 and F-7 fertilization treatments, although, there was no significant difference $(\mathrm{P}>0.05)$ among them. The high $\mathrm{CP}$ yield $(\mathrm{P}<0.05)$ of tuber also observed for F-4 and F-5 fertilization treatments were not significantly different $(\mathrm{P}>0.05)$ between them, but were all significantly higher than the control treatment. The results of the growth attributes showed that the N-K application tended to increase the plant height compared with F-0 treatment (Table 03). The control treatment (F0 ) had a smaller number of leaves and branches per plant than fertilized treatments. Moreover, the treatments were applied with N-K showed a higher number of leaves per plant than other treatments and it was observed in F-5 followed by F-4 (Table 3). The application of N fertilizer together with K (F-4 and F-5) showed a more pronounced effect on the foliage yield compared with the control treatment (Table 03). Similar results were also obtained in the tuber, although, there was no significant difference $(\mathrm{P}>0.05)$ among them (Table 4$)$. The foliage yield peaked at F-4, but the tuber yields obtained at F-5 in this experiment. Both foliage and tuber yields generally increased in all treatments with increasing rates of fertilizer application, however, it tended to decrease with a higher rate of N$\mathrm{K}$ dose at F-7 and F-8.

Table 3. Effect of fertilizer application on protein\%, growth characteristics and yielding of cassava foliage

\begin{tabular}{|c|c|c|c|c|c|c|c|}
\hline \multirow{2}{*}{$\begin{array}{l}\text { Fertilization rate } \\
\mathrm{N}-\mathrm{P}-\mathrm{K}(\mathrm{kg} / \mathrm{ha})\end{array}$} & \multicolumn{2}{|c|}{$\begin{array}{c}\text { Chemical } \\
\text { composition }\end{array}$} & \multicolumn{3}{|c|}{$\begin{array}{c}\text { Growth } \\
\text { characteristics }\end{array}$} & \multicolumn{2}{|c|}{$\begin{array}{c}\text { Yielding } \\
(\mathrm{kg} / \mathrm{ha} \mathrm{DM})\end{array}$} \\
\hline & $\mathrm{DM}(\%)$ & $\mathrm{CP}(\%)$ & Plant height $(\mathrm{cm})$ & Leaf no./ plant & $\begin{array}{l}\text { Branches/ } \\
\text { plant }\end{array}$ & Foliage & Protein \\
\hline $\mathrm{F}-0\left(\mathrm{~N}_{0}-\mathrm{P}_{50}-\mathrm{K}_{0}\right)$ & 25.81 & 12.54 & $149.60^{b}$ & $229.33^{c}$ & $7.67^{b}$ & $1479.33^{\mathrm{d}}$ & $185.30^{\mathrm{d}}$ \\
\hline $\mathrm{F}-1\left(\mathrm{~N}_{0}-\mathrm{P}_{50}-\mathrm{K}_{100}\right)$ & 25.70 & 13.20 & $166.13^{\mathrm{ab}}$ & $307.67^{\mathrm{abc}}$ & $9.00^{\mathrm{ab}}$ & $1821.83^{\mathrm{cd}}$ & $239.79^{\mathrm{bcd}}$ \\
\hline $\mathrm{F}-2\left(\mathrm{~N}_{0}-\mathrm{P}_{50}-\mathrm{K}_{250}\right)$ & 25.54 & 13.25 & $160.07^{\mathrm{ab}}$ & $394.33^{\mathrm{ab}}$ & $12.67^{\mathrm{ab}}$ & $1810.43^{\mathrm{cd}}$ & $238.50^{\mathrm{bcd}}$ \\
\hline $\mathrm{F}-3\left(\mathrm{~N}_{50}-\mathrm{P}_{50}-\mathrm{K}_{0}\right)$ & 24.79 & 13.64 & $156.67^{\mathrm{ab}}$ & $291.00^{\mathrm{bc}}$ & $13.00^{\mathrm{ab}}$ & $1494.13^{\mathrm{d}}$ & $204.07^{\mathrm{cd}}$ \\
\hline $\mathrm{F}-4\left(\mathrm{~N}_{50}-\mathrm{P}_{50}-\mathrm{K}_{100}\right)$ & 24.99 & 13.80 & $183.60^{\mathrm{a}}$ & $395.00^{\mathrm{ab}}$ & $12.67^{\mathrm{ab}}$ & $2930.93^{\mathrm{a}}$ & $404.79^{\mathrm{a}}$ \\
\hline $\mathrm{F}-5\left(\mathrm{~N}_{50}-\mathrm{P}_{50}-\mathrm{K}_{250}\right)$ & 25.58 & 13.82 & $182.20^{\mathrm{a}}$ & $435.00^{\mathrm{a}}$ & $13.00^{\mathrm{ab}}$ & $2684.73^{\mathrm{a}}$ & $370.87^{\mathrm{a}}$ \\
\hline $\mathrm{F}-6\left(\mathrm{~N}_{100}-\mathrm{P}_{50}-\mathrm{K}_{0}\right)$ & 25.96 & 13.58 & $162.87^{\mathrm{ab}}$ & $299.00^{\mathrm{abc}}$ & $13.00^{\mathrm{ab}}$ & $2102.23^{b c}$ & $285.71^{b}$ \\
\hline F-7 $\left(\mathrm{N}_{100}-\mathrm{P}_{50}-\mathrm{K}_{100}\right)$ & 27.16 & 14.09 & $164.47^{\mathrm{ab}}$ & $363.67^{\mathrm{abc}}$ & $14.33^{\mathrm{a}}$ & $2528.53^{\mathrm{ab}}$ & $356.24^{\mathrm{a}}$ \\
\hline $\mathrm{F}-8\left(\mathrm{~N}_{100}-\mathrm{P}_{50}-\mathrm{K}_{250}\right)$ & 24.87 & 13.96 & $165.07^{\mathrm{ab}}$ & $336.00^{\mathrm{abc}}$ & $12.33^{\mathrm{ab}}$ & $1877.73^{\mathrm{cd}}$ & $260.78^{\mathrm{bc}}$ \\
\hline SEM & 0.32 & 0.15 & 12.1 & 2.46 & 0.53 & 99.68 & 14.94 \\
\hline$P$ value & 0.859 & 0.399 & 0.0001 & 0.002 & 0.022 & 0.0001 & 0.0001 \\
\hline
\end{tabular}

a-d Values with different superscript on the same column are significantly different $(\mathrm{P}<0.05)$. 
Table 4. Effect of fertilizer application on protein percent and yielding of cassava tuber

\begin{tabular}{lccccc}
\hline Fertilization rate & \multicolumn{2}{c}{ Chemical composition } & & \multicolumn{2}{c}{ Yielding $(\mathrm{kg} / \mathrm{ha}$ DM $)$} \\
\cline { 2 - 3 } \cline { 5 - 6 } N-P-K $(\mathrm{kg} / \mathrm{ha})$ & $\mathrm{DM}(\%)$ & $\mathrm{CP}(\%)$ & & Tuber & Protein \\
\hline F-0 $\left(\mathrm{N}_{0}-\mathrm{P}_{50}-\mathrm{K}_{0}\right)$ & 23.18 & $0.87^{\mathrm{b}}$ & & $4639.20^{\mathrm{b}}$ & $40.82^{\mathrm{c}}$ \\
F-1 $\left(\mathrm{N}_{0}-\mathrm{P}_{50}-\mathrm{K}_{100}\right)$ & 25.67 & $1.00^{\mathrm{ab}}$ & & $6115.80^{\mathrm{ab}}$ & $61.12^{\mathrm{ab}}$ \\
F-2 $\left(\mathrm{N}_{0}-\mathrm{P}_{50}-\mathrm{K}_{250}\right)$ & 25.14 & $0.99^{\mathrm{ab}}$ & & $7229.50^{\mathrm{ab}}$ & $71.60^{\mathrm{abc}}$ \\
F-3 $\left(\mathrm{N}_{50}-\mathrm{P}_{50}-\mathrm{K}_{0}\right)$ & 26.06 & $1.13^{\mathrm{ab}}$ & & $6401.40^{\mathrm{ab}}$ & $73.35^{\mathrm{abc}}$ \\
F-4 $\left(\mathrm{N}_{50}-\mathrm{P}_{50}-\mathrm{K}_{100}\right)$ & 26.55 & $1.25^{\mathrm{a}}$ & & $9124.40^{\mathrm{a}}$ & $114.07^{\mathrm{a}}$ \\
F-5 $\left(\mathrm{N}_{50}-\mathrm{P}_{50}-\mathrm{K}_{250}\right)$ & 25.07 & $1.19^{\mathrm{ab}}$ & & $9474.10^{\mathrm{a}}$ & $114.62^{\mathrm{a}}$ \\
F-6 $\left(\mathrm{N}_{100}-\mathrm{P}_{50}-\mathrm{K}_{0}\right)$ & 25.39 & $1.28^{\mathrm{a}}$ & & $6363.70^{\mathrm{ab}}$ & $81.91^{\mathrm{abc}}$ \\
F-7 $\left(\mathrm{N}_{100}-\mathrm{P}_{50}-\mathrm{K}_{100}\right)$ & 26.32 & $1.24^{\mathrm{a}}$ & & $7766.00^{\mathrm{ab}}$ & $96.59^{\mathrm{ab}}$ \\
F-8 $\left(\mathrm{N}_{100}-\mathrm{P}_{50}-\mathrm{K}_{250}\right)$ & 25.75 & $1.32^{\mathrm{a}}$ & & $6897.60^{\mathrm{ab}}$ & $85.90^{\mathrm{ab}}$ \\
\hline SEM & 0.36 & 0.04 & & 311.06 & 4.96 \\
P value & 0.455 & 0.115 & & 0.0001 & 0.0001 \\
\hline
\end{tabular}

${ }^{\mathrm{a}-\mathrm{c}}$ Values with different superscript on the same column are significantly different $(\mathrm{P}<0.05)$.

In this experiment, the control treatment without $\mathrm{N}$ and $\mathrm{K}$ fertilization produced lower $\mathrm{CP}$ content compared with other treatments. Ravindran (1993) reported that the foliage contains approximately $21 \% \mathrm{CP}$ with a range from 17 to $40 \% \mathrm{CP}$ depending on cultivar, maturity, sampling procedure, soil fertility and climate. Nitrogen increased the chlorophyll of leaves thereby promoting the photosynthetic capacity of the plant, plays a part in the manufacture of proteins and is also responsible for high yield in plants. The $\mathrm{CP}$ yields of foliage and tuber generally, increased in all treatments as compared to control with increasing rates of $\mathrm{N}$ fertilizer application in this experiment. The increase in protein content with $\mathrm{N}$ fertilization is in agreement with the finding of Mahmud et al., (2003). Potassium, on the other hand, promotes $\mathrm{CO}_{2}$ assimilation and translocation of carbohydrates from leaves to the tubers and tuberous roots of crops where carbohydrates are the main storage material (Howeler, 2002).

The control plots recorded the shortest plants in height with the lowest number of leaves and branches. The superior growth attributes obtained by the application of $\mathrm{N}$ and $\mathrm{K}$ in this experiment had been reported by Uwah et al., (2013). The positive response of growth characters to the applied nutrients is suggested to attributable to their role in cell multiplication and photosynthesis which gave rise to an increase in size and length of leaves and stems. Nitrogen is a major element (Mosier et al., 2004) that is essential for the synthesis of amino acids, nucleic acids and some organic acids which is necessary for plant growth and development and its limits reduce yield (Zhao et al., 2005). Okpara et al., (2010) reported that plant height was increased by the application of K up to $150 \mathrm{~kg} / \mathrm{ha}$.

Fertilization resulted in higher foliage and tuber yields in the fertilized plots than the control. This observation supports the findings of Gomez et al., (1980) who obtained higher cassava yield when fertilizer was applied. Molina and EI-Sharkawy (1995) reported that fertilization induced the production of the more vigorous plant increased nutrient recycling from fallen leaves and improved the quality of the planting material. The increase in fodder yield with fertilizer application may be due to greater plant height, higher stem diameter, a higher number of leaves per plant and greater leaf area per plant (Mahmud et al., 2003). Hence, Mehdi et al., (2007) stated that the positive response of tuber yield and yield components to increased rates of $\mathrm{N}$ and $\mathrm{K}$ could be adduced to high starch synthesis and translocation activities stimulated by $\mathrm{N}$ and $\mathrm{K}$ application.

The effect of different nitrogen and potassium levels on HCNp content and DM yield of cassava were also presented in Figures 2 and 3, respectively. In which, the highest foliage and tuber yields and the lowest HCNp content were observed in $\mathrm{N}_{50}$ for different nitrogen level and in $\mathrm{K}_{100}$ and $\mathrm{K}_{250}$ for different potassium level. Parkes et al., (2012) reported that tuber yields generally increased in all cassava genotypes with increasing rates of fertilizer application up to $\mathrm{N}_{120}-\mathrm{K}_{180}$. However, they recommended that the economic rate of the fertilizer application for all genotypes was $\mathrm{N}_{60}-\mathrm{K}_{90}$. Viewing both yield and $\mathrm{HCNp}$ contents, the results of the present experiment exhibited that F-4 and F-5 fertilizer combinations gave the higher cassava yield with lower HCNp content than without N-K fertilization. Furthermore, the maximum dry matter yield and lowest HCNp content in foliage and tuber were obtained by the application of $\mathrm{N}_{50}$ and $\mathrm{K}_{100-250}$ fertilization rates. Therefore, the combination of $\mathrm{N}_{50}$ and $\mathrm{K}_{100}$ fertilization appeared appropriate for optimum yield and $\mathrm{HCNp}$ reduction in our study. Bolhuis 
(1954) had set the following classification of toxicity according to HCNp content: $0-50 \mathrm{mg} / \mathrm{kg}$, innocuous or harmless, $50-100 \mathrm{mg} / \mathrm{kg}$ moderately toxic and $>100 \mathrm{mg} / \mathrm{kg}$ dangerous or toxic. Therefore, this study revealed that the control treatment had the HCNp level $(129.49 \mathrm{mg} / \mathrm{kg})$ considered a poisonous level while other treatments were moderately poisonous levels $(51.89-90.00 \mathrm{mg} / \mathrm{kg})$.

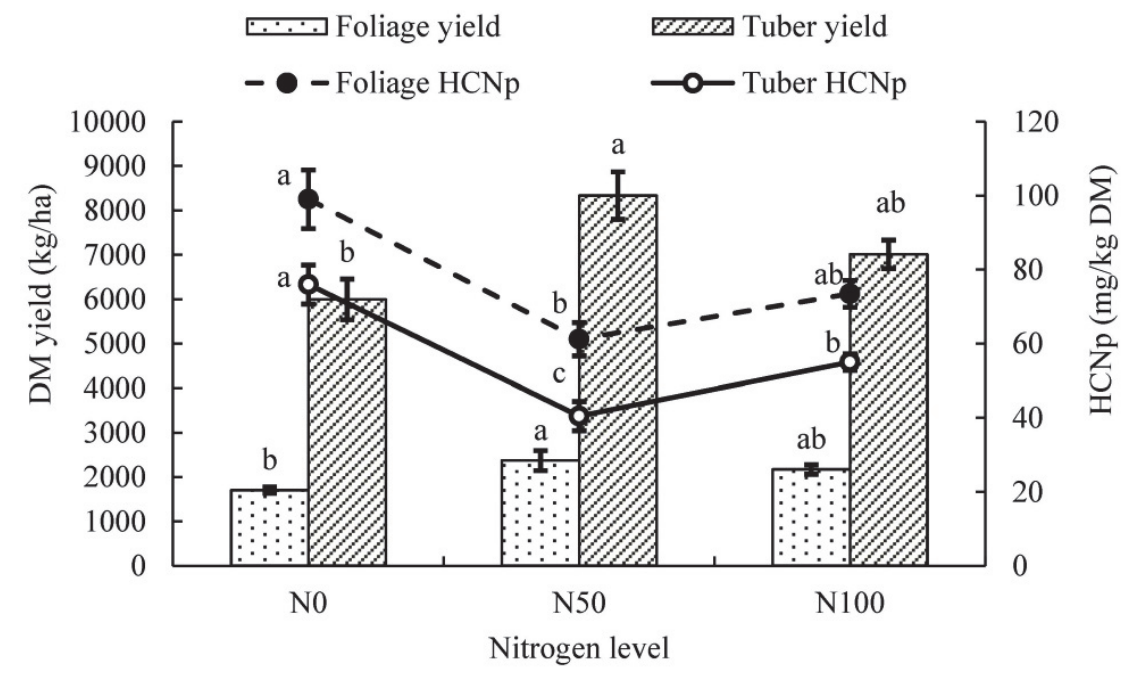

Figure 2. Effect of different nitrogen levels on hydrocyanic acid potential (HCNp) content and DM yield of cassava foliage and tuber

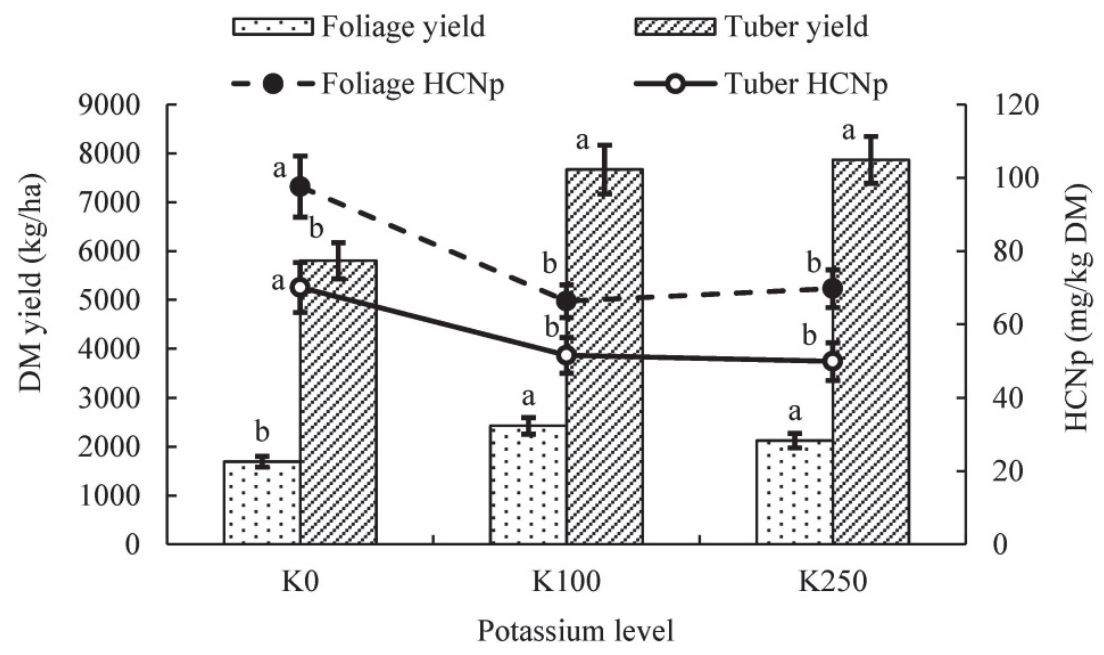

Figure 3. Effect of different potassium levels on hydrocyanic acid potential ( $\mathrm{HCNp}$ ) content and DM yield of cassava foliage and tuber

\section{Conclusions}

This research's findings indicated that cyanide poisoning can be managed by management practices such as the appropriate amount of fertilization for provision safe cassava crop for livestock. Thus, it could be recommended that the nitrogen $(\mathrm{N}: 50 \mathrm{~kg} / \mathrm{ha})$ and potassium $(\mathrm{K}: 100-250 \mathrm{~kg} / \mathrm{ha})$ should be used to reduce cyanogen contents for safe utilization and increased cassava foliage and tuber yields.

\section{Conflict of interest}

The authors declare that they have no conflict of interest.

\section{References}

AOAC. (1985). Association of Official Analytical Chemists. Official Method of Analysis. Association of Official Analytical Chemists, Washington, D.C. 
Ayoola, O. T., \& Makinde, E. A. (2007). Fertilizer treatment effects on performance of cassava under two planting patterns in a cassava-based cropping system in south west Nigeria. Research Journal of Agriculture and Biological Sciences, 3(1), 13-20.

Bolhuis, G. G. (1954). The toxicity of cassava root. Netherlands Journal of Agricultural Science, 2(3), 176-185.

Bradbury, J. H., Egan, S. V., \& Lynch, M. J. (1991). Analysis of cyanide in cassava using acid hydrolysis of cyanogenic glucosides. Journal of the Science of Food and Agriculture, 55(2), 277-290. https://doi.org/10.1002/jsfa.2740550213

Bradbury, M. G., Egan, S. V., \& Bradbury, J. H. (1999). Picrate paper kits for determination of total cyanogens in cassava roots and all forms of cyanogens in cassava products. Journal of the Science of Food and Agriculture, 79(4), 593-601. https://doi.org/10.1002/(SICI)1097-0010(19990315)79:4<593:AID- JSFA222>3.0.CO;2-2

Cardoso, A.P., Mirione, E., Ernesto, M., Massaza, F., Cliff, J., Haque, M. R., \& Bradbury, J. H. (2005). Processing of cassava roots to remove cyanogens. Journal of Food Composition and Analysis, 18(5), 451-460. https://doi.org/10.1016/j.jfca. 2004.04.002

Eggum, B. O. (1970). The protein quality of cassava leaves. British Journal of Nutrition, 24(3), 761-786. https://doi.org/10.1079/BJN19700078

Gomez, J. C., Howeler, R. H., \& Webber, E. J. (1980). Cassava production in low fertility soils. In M.J.C. Toro, \& M. Graham (Eds.), Cassava cultural practices. Bowker Publ. Co. Ltd., Epping. U.K.

Howeler, R. H. (1985). Potassium nutrition of cassava. In: Proceedings of the international symposium on potassium in agriculture. Atlanta, madison, Wisconsin. p. 819-841.

Howeler, R. H. (2002). Cassava mineral nutrition and fertilization. In R. J. Hillocks, J. M. Thresh, \& A. C. Bellotti (Eds), Cassava: Biology, Production and Utilization. CAB International, Wallingford, Oxon, UK.

Hue, K. T., Van, D. T. T., Ledin, I., Wredle, E., \& Sporndly, E. (2012). Effect of harvesting frequency, variety and leaf maturity on nutrient composition, hydrogen cyanide content and cassava foliage yield. Asian-Australian Journal of Animal Science, 25(12), 1691-1700. http://dx.doi.org/10.5713/ajas.2012.12052

Mahmud, K., Ahmad, I., \& Ayub, M. (2003). Effect of nitrogen and phosphorus on the fodder yield and quality of two sorghum cultivars (Sorghum bicolor L.). International Journal of Agriculture and Biology, 5(1), 61-63.

Mehdi, S. M., Sarfraz, M., \& Hafeez, M. (2007). Response of rice advance line PB-95 to potassium application in saline-sodic soil. Pakistan Journal of Biological Science, 10(17), 2935-2939. https://doi.org/10.3923/pjbs.2007.2935.2939

Molina, J. L., \& EI-Sharkawy, M. A. (1995). Increasing crop productivity in cassava by fertilizing production of planting material. Field Crop Research, 44(2-3), 151-157. https://doi.org/10.1016/0378-4290(95)00082-8

Mosier, A. R., Syers, J. K., \& Freney, J. R. (2004). Nitrogen fertilizer: an essential component of increased food, feed and fiber production. In A. R. Mosier, J. K. Syers, \& J. R. Freney (Eds.), Agriculture and the Nitrogen cycle. Assessing the impacts of fertilizer use on food production and the environment (pp. 3-15). Scope, island press. Washington DC. 65.

Nambisan, B. (2010). Strategies for elimination of cyanogens from cassava for reducing toxicity and improving food safety. Food Chemistry and Toxicology, 49(3), 690-693. https://doi.org/10.1016/j.fct.2010.10.035

O’Brien, G. M., Chow, E. P. L., \& Price, R. K. (2007). Initial evaluation of field-friendly extraction procedure for the enzymatic assay of cassava cyanogens. International Journal of Food Science and Technology, 42(8), 999-1006. https://doi.org/10.1111/j.1365-2621.2006.01396.x

Okigbo, B. N. (2001). Nutritional implication of projects giving high priority to the production of staples of low nutritive quality: The case for cassava (Manihot esculenta, Crantz) in the humid tropics of West Africa. International Institute of Tropical Agriculture, Ibadan, Nigeria.

Okpara, D. A., Agoha, U. S., \& Iroegbu, M. (2010). Response of cassava variety TMS/98/0505 to potassium fertilization and time of harvest in South Eastern Nigeria. Nigeria Agr. J., 41(1), 91-100.

Onwueme, I. C., \& Charles, W. B. (1994). Tropical root and tuber crops: Production perspectives and future prospects. FAO plant production and protection paper. FAO, Rome.

Parkes, E. Y., Allotey, D. F. K., Lotsu, E., \& Akuffo, E. A. (2012). Yield performance of five cassava genotypes under different fertilizer rates. Internatinal Journal of Agricultural Science, 2(5), 173-177.

Peech, M., Cowan, R. L., \& Baker, J. H. (1962). A critical study of the BaCL2-triethanolamine and the Ammonium 
acetate methods for determining the exchangeable hydrogen content of soils. Soil Science Society of America Journal, 26(1), 37-40. https://doi.org/10.2136/sssaj1962.03615995002600010 010x

Peter, K. B., \& Birger, L. M. (2002). Dhurrin synthesis in sorghum is related at the transcriptional level and induced by nitrogen fertilization in order plants. Plant Physiology, 129, 1222-1231. https://doi.org/10.1104/pp.000687

Putthacharoen, S., Howeler, R. H., Jantawat, S., \& Vichukit, V. (1998). Nutrient uptake and soil erosion losses in cassava and six other crops in a Psamment in eastern Thailand. Field Crops Research, 57(1), 113-126. https://doi.org/10.1016/s0378-4290(97)00119-6

Ravindran, V. (1993). Utilization of cassava (Manihot esculenta, Crantz) leaves in animal nutrition. Journal of National Scientific Council Sri Lanka, 21, 1-26.

Ravindran, V., Kornegay, E. T., Webb, K. E. \& Rajaguru, A. S. B. (1982). Nutrient characterization of some feedstuffs of Sri Lanka. Journal of National Agricultural Society, Ceylon, 19, 19-32.

Rogers, D. J., \& Milner, M. (1963). Amino acid profile of manioc leaf protein in relation to nutritive value. Economic Botany, 17, 211-216. https://doi.org/10.1007/BF 02859438

Sarfo, E. Y., Ofori, F., \& Dennis, E. A. (1998). Report of the Sub-Committee on fertilizer use for the national agricultural research programme (NARP). Accra. Ghana.

Sher, A., Ansar, M., Hassan, F. U., Shabbir, G., \& Malik, M. A. (2012). Hydrocyanic acid content variation amongst sorghum cultivars grown with varying seed rates and nitrogen levels. International Journal of Agriculture and Biology, 14(5), 720-726.

SPSS. (2007). Statistical Package for the Social Science. Version 16.0. SPSS Inc. United State of America.

Truog, E. (1930). The determination of readily available phosphorus in soils. American Society Agrono, 22, 874882.

Uwah, D. F., Effa, E. B., Ekpenyong, L. E., \& Akpan I. E. (2013). Cassava (Manihot esculenta, Crantz) performance as influenced by nitrogen and potassium fertilizers in Uyo, Nigeria. Journal of Animal and Plant Science, 23(3), 550-555.

Worthington, V. (2001). Nutritional quality of organic versus conventional fruits, vegetables and grains. The Journal of Alternative and Complementary Medicine, 7(2), 161-173. https://doi.org/10.1089/ 107555301750164244

Zhao, D., Reddy, K. R., Kakani, V. G., \& Reddy, V. R. (2005). Nitrogen deficiency effects on plant growth, leaf photosynthesis and hyperspectral reflectance properties of sorghum. European Journal of Agronomy, 22(4), 391-403. https://doi.org/10.1016/j.eja.2004.06.005

\section{Copyrights}

Copyright for this article is retained by the author(s), with first publication rights granted to the journal.

This is an open-access article distributed under the terms and conditions of the Creative Commons Attribution license (http://creativecommons.org/licenses/by/4.0/). 